\title{
Contributing factors in judgment of fairness by monetary value
}

\author{
David Nicoladie Tam \\ From Twentieth Annual Computational Neuroscience Meeting: CNS*2011 \\ Stockholm, Sweden. 23-28 July 2011
}

Given that we have developed for emotional response (Emotional-Gain Model) [1-4] and a model for fairness (Fairness-Equity Model) [5] that quantified emotional bias and fairness bias, we will use these models to reveal the hidden factors contributing to the emotional bias and fairness bias. Using the Ultimatum Game (UG) with human subjects to split a sum of money, we compare the responses between sharing $\$ 10$ vs. $\$ 10$ million. The results show that the proportionality relationship in fairness perception is skewed according to the amount of money as well as the relative ratio of equity. The proportionality relationship in emotional response is also skewed by the amount of money and the relative ratio of disparity. This quantifies the specific fairness bias and emotional bias based on the monetary value of the disparity (or equity) between the shares. The biases are characterized by the shifting of the fairness-curve in the fairness-equity space, and the shifting of the emotionalcurve in the emotional-gain space graphically. The result also reveals the objectivity of perception in spite of the subjectivity of their perception to inequitable share.

Published: 18 July 2011

\section{References}

1. Tam D: EMOTION-I Model: A Biologically-Based Theoretical Framework for Deriving Emotional Context of Sensation in Autonomous Control Systems. The Open Cybernetics \& Systemics Journal 2007, 1:28-46.

2. Tam D: EMOTION-II Model: A Theoretical Framework for Happy Emotion as a Self-Assessment Measure Indicating the Degree-of-Fit (Congruency) between the Expectancy in Subjective and Objective Realities in Autonomous Control Systems. The Open Cybernetics \& Systemics Journal 2007, 1:47-60.

3. Tam DN: Computation in Emotional Processing: Quantitative confirmation of proportionality hypothesis for angry unhappy emotional intensity to perceived loss. Cognitive Computation .

Correspondence: dtam@unt.edu

Department of Biological Sciences, University of North Texas, Denton, TX 76203, USA

\section{BioMed Central}

(0) 2011 Tam; licensee BioMed Central Ltd. This is an open access article distributed under the terms of the Creative Commons Attribution License (http://creativecommons.org/licenses/by/2.0), which permits unrestricted use, distribution, and reproduction in any medium, provided the original work is properly cited.
4. Tam DN: Cognitive perception of happy emotion: proportionality relationship of emotional intensity to the gain/loss-ratio when getting what one wants - an experimental confirmation., (submitted).

5. Tam DN: Objectivity in subjective perception of fairness: relativity in proportionality relationship with equity by switching frame-of-reference - a fairness-equity model., (submitted).

doi:10.1186/1471-2202-12-S1-P329

Cite this article as: Tam: Contributing factors in judgment of fairness by monetary value. BMC Neuroscience 2011 12(Suppl 1):P329.

\section{Submit your next manuscript to BioMed Central and take full advantage of:}

- Convenient online submission

- Thorough peer review

- No space constraints or color figure charges

- Immediate publication on acceptance

- Inclusion in PubMed, CAS, Scopus and Google Scholar

- Research which is freely available for redistribution Submit your manuscript at
www.biomedcentral.com/submit 